ARTIGO

INTEGRA O BLOCO 3

\author{
Contato \\ Escola da Cidade - Faculdade de \\ Arquitetura e Urbanismo \\ Rua General Jardim, n. 65 \\ 01223-011 - São Paulo - São Paulo - Brasil \\ amaliasantos@gmail.com
}

\section{ABAIXO, AO LADO, \\ NO PASSADO: A \\ REPRESENTAÇÃO DE \\ INDÍGENAS PELAS \\ ELITES PAULISTAS, DOS SÉCULOS XVIII AO XX'}

\section{- Amália Cristovão dos Santos ${ }^{2}$}

Escola da Cidade - Faculdade de Arquitetura e Urbanismo

São Paulo - São Paulo - Brasil

\title{
Resumo
}

Os jornais paulistanos publicados no período do IV Centenário da Fundação da Cidade, com artigos, poesias, iconografias e propagandas, permitem apreender a culminação de processos de longa duração de construção, transformação e apropriação de imaginários criados desde a América portuguesa, tendo como elementos centrais as relações entre colonos (e seus descendentes), grupos indígenas e o território. A bravura e heroísmo dos "sertanistas", a nobreza dos "paulistas" e a disciplina e regramento dos "agricultores" são lastros tomados por historiadores e elites paulistas no século XX, em busca de representações adequadas à centralidade que o estado adquirira no panorama econômico e político nacional, cristalizando a obliteração dos ameríndios, que passam de aliados e até familiares indispensáveis para incômodos coadjuvantes de um passado esgotado.

\section{Palavras-chave}

São Paulo (cidade) - Indígenas - Paulistas - Representações - Imaginário.

\footnotetext{
1 Artigo não publicado em plataforma preprint. Todas as fontes e bibliografia utilizadas são referenciadas no artigo.

2 Doutora pela Faculdade de Arquitetura e Urbanismo da Universidade de São Paulo (FAU-USP), em 2018. Atualmente, professora de graduação no Departamento de História e professora e coordenadora de curso lato sensu de pós-graduação, ambos na Escola da Cidade - Faculdade de Arquitetura e Urbanismo, em São Paulo - SP, Brasil.
} 


\section{- Amália Cristovão dos Santos}

Escola da Cidade - Faculdade

de Arquitetura e Urbanismo

São Paulo - São Paulo - Brazil

\begin{abstract}
São Paulo's newspapers from the quadricentennial of the city's foundation, containing papers, poetry, iconographies, and advertising, allows one to apprehend the culmination of a long-term process of development, transformation, and appropriation of the imagery created since the Portuguese America, founded on the relations between settlers, indigenous groups, and the territory. The bravery and heroism of "sertanistas", the nobility of "paulistas", and the discipline of the "agricultores" (farmers) are the basis for the suitable representations created by historians and São Paulo's elite in the $20^{\text {th }}$ century, parallel to the state's newly acquired political and economic centrality, consolidating the obliteration of the indigenous population, that go from indispensable allies and even relatives to troublesome second-class citizens from an exhausted past.
\end{abstract}

\title{
Keywords
}

São Paulo (city) - Indigenous - Paulistas - Representations - Imaginary. 


\section{1 - Introdução}

As comemorações do IV Centenário da Fundação da Cidade de São Paulo (1954) foram momento de intenso ufanismo e celebração dos heróis do passado e do presente. Projetando-se àquela altura como principal centro econômico do país, a cidade viu-se tomada por ações e discursos que cristalizavam ideias de uma suposta predestinação de sua população à grandeza. Os jornais da capital produziram conteúdos exclusivos para a data, entre artigos científicos, escritos literários e gravuras, devidamente complementadas com anúncios de companhias públicas e privadas e organizações variadas, igualmente marcadas pelo tema geral. Em tais produções, é reproduzida à exaustão a imagem do paulista de outrora, o bandeirante de barba hirsuta, longas botas e olhar assertivo, elo entre o passado glorioso e o futuro de progresso; perto dele, frequentemente figura o indígena, marcadamente distinto daquele, com suas penas e arco. Sua posição consagra-o no papel de coadjuvante da maravilhosa aventura do desenvolvimento desse território, a partir de um lugar de contribuição fundante - contudo já irremediavelmente esgotada. Neste artigo, exploro os elementos que compõem essa configuração de poder na relação entre paulistas e indígenas, culminando nas representações de meados do século XX, entendendo-as como parte de um dilatado movimento de criações, apagamentos, empréstimos e retomadas do imaginário sobre os homens de São Paulo, difuso em cartografias, genealogias, artigos, cartas e historiografias produzidas por essas elites.

\section{2 - Terra desbravada, terra habitada}

Nos textos introdutórios da $5^{\mathrm{a}}$ edição da Nobiliarquia Paulistana Histórica e Genealógica de Pedro Taques, Affonso Taunay remete-se ao genealogista como "historiador desses bandeirantes com quem realizava todas as afinidades" (TAUNAY in LEME, 1980, p. 41). A vontade de aproximação - e atribuição de sentido - não escapou também a Jaime Cortesão, para quem Alexandre de Gusmão, apesar de imbuído de patente racionalidade e ilustração, seria "penetrado de espírito bandeirante" (CORTESÃO, 2006, p. 340). As imagens heroicas dos homens paulistas, fixadas no imaginário do século $\mathrm{XX}$, marcadamente no período de engrandecimento político do estado, começaram a ser formuladas muito antes disso, em meio a disputas entre sua população, grupos indígenas e a administração colonial e imperial. Entre o século XVIII e meados do seguinte, as relações entre colonos de São Paulo e nativos foi infalivelmente transfigurada. Se primeiro, aos olhos dos demais agentes da 
colonização, os paulistas ocupavam posição dúbia, conformando uma cultura própria e apresada entre demonstrações de lealdade à monarquia portuguesa e acusações de insubordinação, passam depois a diferenciar-se do elemento natural, construindo para si um passado e um presente pautados pela distinção - superando, assim, as ambiguidades das alianças e articulações que permitiram suas ações de exploração e conquista territorial. É no bojo dos interesses das elites locais da capitania paulista, ao longo dos séculos em tela, que se pode enquadrar as transformações e retomadas do imaginário sobre os indígenas habitantes desse território, ora exaltados por seu domínio do território e sua disponibilidade, ora detratados por sua barbárie e recorrente insubmissão.

A releitura das relações construídas nos séculos XVIII e XIX entre ameríndios e não ameríndios, articuladas aos diferentes usos da terra ao longo desse período - em explorações extrativistas, na expansão das fronteiras de ocupação e na agricultura de exportação -, elucida os mecanismos de acúmulo e sobreposição que permitiram no século XX, a um só tempo, que os paulistas posicionassem simbolicamente os grupos indígenas em um passado fundante e combatessem-nos frontalmente no presente, sob um horizonte declarado de extinção. No artigo que se segue, apontarei como os debates acerca das relações entre paulistas, grupos nativos e território na construção de imagens e representações podem contribuir para a revisão da historiografia paulística, ${ }^{3}$ de suas interlocuções e de seus desdobramentos. Vinculada originalmente à produção do Instituto Histórico e Geográfico de São Paulo (IHGSP), fundado na Primeira República, essa produção construiu um discurso sobre os paulistas marcado por características como excepcionalidade e liderança, em um contexto de busca de reconfigurações políticas no cenário nacional (SAES in ODALIA, CALDEIRA, 2010). A mitologia bandeirante se assim podemos chamá-la - talvez tenha sido um dos ápices dos processos de construção de imaginário e ressignificação do passado dessa população. Dentro dessa narrativa, a excepcionalidade do bandeirante paulista seria o elemento-chave na compreensão do sucesso que a antiga província e agora estado teria obtido, notadamente com a agricultura cafeeira, e justificaria também sua demanda por centralidade no cenário político republicano. O

3 Tomamos o termo de Ilana Blaj (2002). 
principal traço de sua atuação seria a expansão das ocupações territoriais ao longo do período colonial. ${ }^{4}$

No início do século XX, a lavoura cafeeira estava em expansão no extremo oeste do estado - em área indicada como "sertão desconhecido" no primeiro mapa provincial paulista, impresso em 1841 e realizado sob os auspícios de Daniel Pedro Müller, ${ }^{5}$ em empreitada conjunta com o desenvolvimento de estatística sobre a província (MÜLLER, 1978), publicada em 1838. Os dois produtos foram encomendas da primeira legislatura provincial paulista, instituída em 1835, e seguiam um reordenamento do olhar para o território, seus recursos e suas populações, em que a racionalidade e a adoção de métodos científicos seriam significantes dos intentos de desenvolvimento da elite administrativa e, de modo geral, devedoras das tentativas da Coroa portuguesa de superar "o problema do atraso em relação à Europa 'moderna'" (NOVAIS, 1984, p. 106).

O supramencionado Quadro estatístico de Müller não traz menção aos grupos indígenas que habitavam e se deslocavam pelas regiões sudoeste e noroeste da província, ainda que sua presença fosse amplamente conhecida pelas sucessivas administrações da capitania e província e pelos religiosos nelas sediados. Foi constante, desde o início da colonização, o debate acerca da necessidade de fixação das populações nativas, e a "vadiação" desses grupos - em sua maioria não sedentários - era vista como sinal de decaimento, desordem e, em fins do século XVIII, apontada como empecilho central para a implantação de agriculturas regulares, que pudessem se configurar como vetores de exportação:

Está visto como a principal causa da falta de lavoura é a vadiação. Há, além disso, outras, que são a falta de ferro para os instrumentos rústicos, a abundância de formigas verme-

\footnotetext{
${ }^{4}$ Em publicação comemorativa da Comissão do IV Centenário da Fundação da Cidade de São Paulo, Affonso Taunay realiza uma síntese desse período, na qual é possível ver a força e a centralidade da expansão territorial na explicação proposta. Grande parte do texto reúne enumerações de bandeiras e batalhas realizadas nos sertões coloniais pelos paulistas, indicando a relevância de suas ações para a configuração da nação, em tom premonitório: "Em terras de São Paulo surgiu o primeiro marco definitivo da colonização portuguêsa no Brasil. Tal circunstância foi como que um símbolo da devassa dos tempos, dado o papel capital que aos paulistas caberia na construção da pátria brasileira". Ver TAUNAY in COMISSÃO DO IV CENTENÁRIO DA FUNDAÇÃO DA CIDADE DE SÃO PAULO, 1953, p. 49-57.

5 Mappa Chorographico da Provincia de São Paulo. Paris: Alexis Orgiazzi, [1841]. 1 mapa, impr:: 100 x $72 \mathrm{~cm}$. Arquivo Público do Estado de São Paulo.
} 
lhas, que fazem inúteis muitas terras lavradias, e de pássaros de bico redondo e o furto de gados, tão necessários para o estrume das terras (RENDON, 1978, p. 6, grifos nossos).

A preocupação assinalada por José Arouche de Toledo Rendon, no relatório escrito durante o governo do capitão-general Bernardo José de Lorena (1788-1797), não era de caráter exclusivamente moral, mas também dizia respeito à necessidade de incutir nos lavradores, existentes e potenciais, a reverência ao trabalho, que os tornaria produtivos e, desse modo, traria progresso à capitania. A vinculação da população à terra era, pois, indispensável para que essa pudesse dar frutos regulares. Na estatística de Müller, o diagnóstico e as ações necessárias aproximam-se das de Rendon:

O territorio em geral é fertil e ameno: são por isso a maior parte dos habitantes Agricultores; porém a arte de Agricultura tem feito pouco progresso; a extensão do terreno, proporcionadamente vasto para seus poucos habitantes, lhes presta meios de escolherem as melhores paragens, d'onde tirem proveito com menos trabalho. (...)

Similhantes causas concorrem para que muitos dos cultivadores não satisfeitos com seus terrenos, vão apoz de outros que tenhão mattas, as quaes destróem para as queimarem, e plantarem, e as abandonão quando ficão em arbustos pouco frondosos, ou em campos, e d'esta maneira a Agricultura em logar de conchegar os habitantes, separou a muitos do seu antigo domicilio (...). (MÜLLER, 1978, p. 24, grifos nossos).

A manutenção dos sítios volantes e da prática da coivara - uso de queimadas para limpar terrenos para plantio, que acaba por desgastá-los rapidamente - era um problema central para a administração provincial e tinha origens certas: se, segundo Rendon, "os lavradores desta capitania são tão vadios", "de todos os mais vadios eram os índios" (RENDON, 1978, p. 2-3). Para esses homens, os nativos estariam com os pés nas desejadas terras do "sertão desconhecido" - e de braços cruzados.

Incógnita, aos olhos da pretensa ou intentada vida civilizada que essas elites buscavam, a região foi suficientemente avaliada e examinada com relação aos planos econômicos e políticos encampados por esses grupos. Potencial havia, mas era preciso desmantelar a ordem vigente naqueles territórios - em grande medida, uma ordem de resistência, com encontros e conflitos entre modos de vida de diversos grupos indígenas, posseiros e grandes fazendeiros. Em meio aos debates sobre possíveis soluções para o impasse da presença indígena nos territórios que interessavam aos planos de modernização, esses grupos eram descritos como agressivos, improdutivos, pouco aptos ao trabalho regular e de difícil relação - não muito diferentemente, portanto, das caracterizações veiculadas no século XX. Nas primeiras décadas do novecentos, a distinção entre "brancos" e "índios", ao menos nos 
discursos científicos e políticos, não tinha mais áreas turvas - não havia mais "mamelucos", "sertanistas" ou qualquer outra relação direta, parental ou por empreitada, entre essas elites e as populações nativas. ${ }^{6}$ Foi a partir da segunda metade do setecentos que os paulistas procuraram se afastar completamente das representações segundo as quais manteriam práticas ou laços familiares originados das articulações estabelecidas com grupos indígenas - eram esses os trunfos dos moradores de São Paulo, exploradores do território colonial em busca de metais e pedras preciosas e frequentemente convocados para abater ou submeter populações indígenas e quilombolas. ${ }^{7}$

As Atas da Câmara de São Paulo mencionam repetidamente as habilidades de nativos como "bons sertanistas", capazes de penetrar os sertões coloniais, localizar recursos de interesse da Coroa e construir caminhos seguros (MACHADO, 1980 [1929], p. 181). A proximidade entre paulistas e indígenas garantiu aos primeiros a apropriação dessas práticas e saberes, forjando um modo de vida híbrido entre os interesses particulares, as relações pouco harmônicas com a administração colonial e as diversas articulações com os autóctones (KOK, 2004, p. 32). Assim como suas "técnicas", a qualificação atribuída aos indígenas de "bons sertanistas" também transbordou para os moradores de São Paulo, sobre os quais eram feitos comentários semelhantes no que tange às habilidades de circulação e vivência nos sertões. Nos paulistas, diferentemente dos nativos e mais do que para outros colonos, fixou-se a denominação "sertanistas". Eram esses os homens experimentados no sertão, que chefiavam dezenas e por vezes centenas de indígenas, além de outros colonos, entregando-se às mais variadas atividades empreendidas nos interiores da América - entradas para prear "negros da terra", guerras contra os "bárbaros gentios" e descobertas de pedras e metais preciosos. ${ }^{8}$

\footnotetext{
"Vale dizer que categorias como "bugreiro", "caboclo" e "caipira", construídas nesse momento, implicavam alguns tipos de mestiçagem, mas não se referiam às elites e à população das principais municipalidades, ficando restrita aos territórios distantes e à vida rural. Uma visada sobre o tema pode ser encontrada no trabalho de Antonio Candido (2001, p. 21-41) sobre a cultura caipira em São Paulo. Maria Luiza Marcílio (2000, p. 161-162) relaciona "caboclo", "caipira" e "mameluco", tendo como aspectos comuns a prática de roças itinerantes e a presença de costumes originários de grupos indígenas.

7 Vale notar, de acordo com estudo pioneiro de Clóvis Moura (1959), que os quilombos eram regularmente compostos por escravizados fugidos bem como por ameríndios.

8 "De modo que se pode escrever sem qualquer exagêro que o caráter fundamental da povoação paulistana nos seus primeiros quase três séculos de existência (aproximadamente de 1554 a 1828) [...] foi o de um arraial de sertanistas" (BRUNO, 1991, p. 96). Na cronologia apresentada por Ernani Silva Bruno (1991, p. 69-96), demasiadamente generalista, a relevância da vila e
} 


\section{Figura 1}

Mapa dos confins do Brazil com as terras da Coroa da Espanha na America Meridional (Mapa das Cortes), 1749

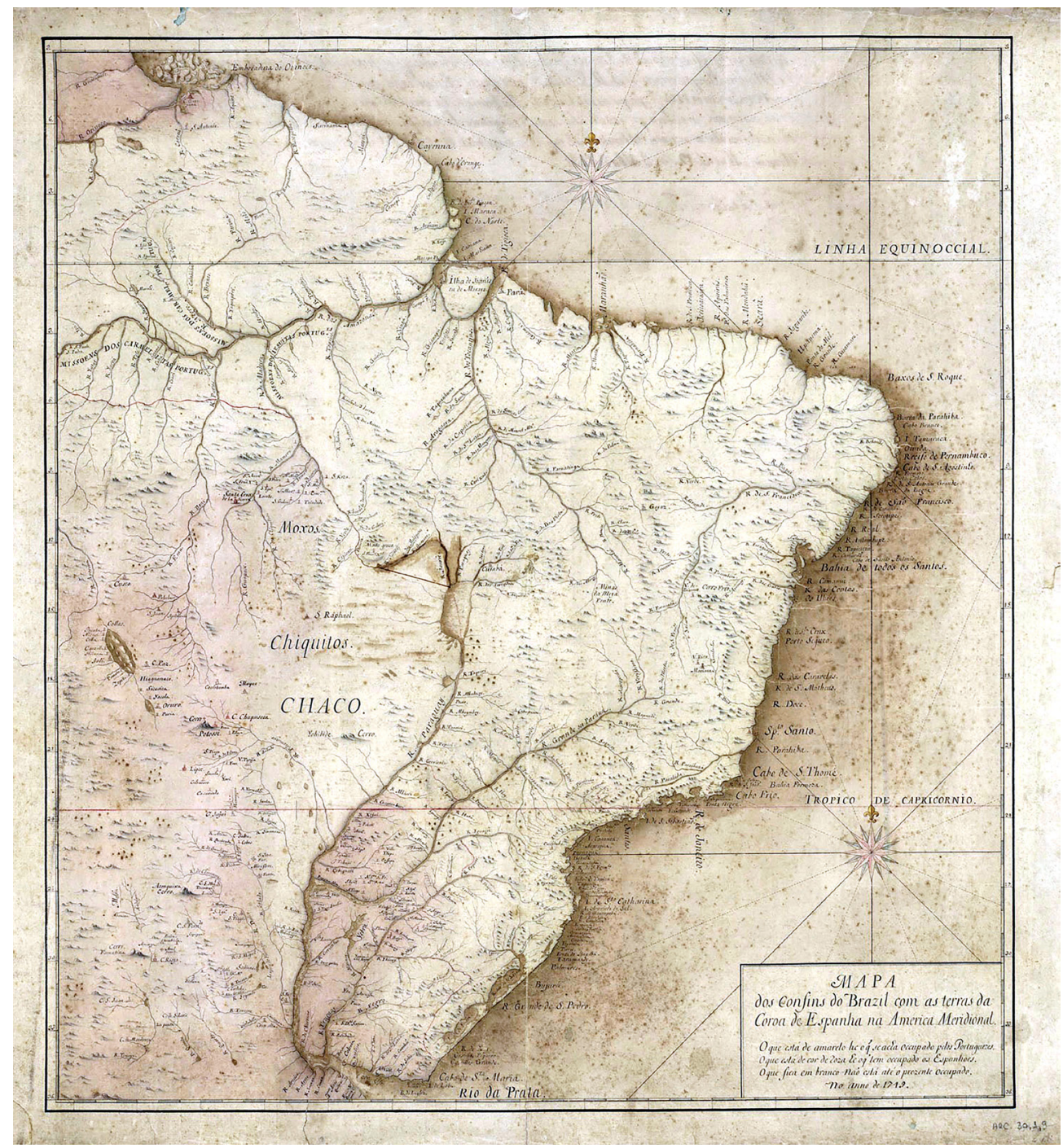

Fonte: Biblioteca Nacional do Rio de Janeiro.

depois cidade de São Paulo estaria em ser o local de preparação das entradas que partiam para os sertões, até o momento de fundação da Academia de Direito, a partir do qual se transformaria sua dinâmica urbana. 
A proximidade entre a territorialidade desses colonos e a dos nativos com os quais se aliaram é apontada em diversos estudos acerca do chamado Mapa das Cortes, assinado por diplomatas de Portugal e Espanha em 1749, ano de sua divulgação, em meio aos procedimentos de assinatura do Tratado de Madrid (1751). ${ }^{9}$ Distintamente dos portugueses, os colonos de São Paulo teriam adotado formas de registro do território explorado próprios dos contatos diretos, que explicariam algumas das imprecisões de partes dessa cartografia:

(...) grande parte dos rios do interior carece de detalhes ou, quando os têm, apresentam notáveis distorções com relação à forma, por provirem de relatos de sertanistas, que avaliam distâncias por dias de percurso, daí se deduzindo latitudes e longitudes imprecisamente (CINTRA, 2009, p. 68, grifos nossos).

Jaime Cortesão (2006, p. 17) classifica como espontâneos os mapeamentos elaborados por sertanistas, "lusos e luso-brasileiros, que consignavam no papel o traçado sumário e empírico dos seus descobrimentos"..$^{10}$ Esses modos de percorrer e quantificar o território seriam advindos da proximidade entre paulistas e indígenas, sendo esses detentores de um "instinto expontâneo" [sic] (CORTESÃO, 2006, p. 307), algo como um dom inato de trânsito espacial, distinto da racionalidade e intencionalidade dos portugueses. Como se vê, a integração entre colonos de São Paulo e nativos era eventualmente vista com receio pela Coroa portuguesa, por torná-los súditos insubordinados, mas se caracterizava também como uma forma de fazer avançar os planos oficiais.

\footnotetext{
9 Mapa dos confins do Brazil com as terras da Coroa da Espanha na América Meridional. [S.l.: s.n.], 1749. 1 mapa ms.: col.; 60 x 54cm. em f. 70 x 64. Biblioteca Nacional do Rio de Janeiro.

${ }^{10}$ Sobre os mapas elaborados por sertanistas, prossegue Cortesão (2006, p. 17-18): “Lusos e luso-brasileiros, igualmente dotados dum agudo sentido do espaço, elaboraram muitas cartas, das quais a grande maioria se perdeu e de cuja existência temos notícia apenas por documentos escritos. Comandantes de tropa, a quem as obrigações militares forçavam a grandes deslocamentos; sertanistas, cujas atividades múltiplas alargavam a muito vastos territórios o raio da ação; e mineradores nômades, por necessidade ou ambição, contribuíram com seus traçados, para uma carta nativa e espontânea do Brasil, em formação, da qual os dois protótipos conhecidos são a 'Demarcação Geográfica do Brasil', feita por João de Abreu Gorjão, cêrca de 1742 e a de Tosi Colombina de 1751, que, em nosso curso de História da Cartografia do Brasil, chamamos 'carta dos caminhos do Brasil' [.] Mas, num, como noutro caso, o cartógrafo pouco mais fêz do que reunir e coordenar num todo único, os traçados ou riscos dos sertanistas de acaso ou profissão".
} 


\section{3 - Entre vícios e virtudes ${ }^{11}$}

As conquistas desses sertanistas, fossem de terras, recursos ou gentes, somaram-se ao longo de mais de quase dois séculos, sem afastá-los, contudo, das imagens de crueldade e sublevação, originadas ainda no início do seiscentos, de quando datam as invasões desses colonos às missões jesuíticas do Guairá. Nesses movimentos, foram sequestrados e levados para São Paulo os indígenas de reduções da região. Os padres lesados nos ataques dirigiam-se ao rei das Coroas ibéricas, pedindo o retorno dos nativos que haviam sido levados, em missivas construídas a partir de uma retórica peculiar. Nas cartas, os sacerdotes descrevem as ações dos "portugueses de São Paulo", associados aos Tupi, como violentas e heréticas, configurando crime contra Deus e a Coroa. Entrevê-se no discurso algo que seria uma especificidade dos colonos dessa região: o contato continuado com grupos indígenas. Foi pelas mãos dos padres agredidos e insultados que tomou forma a chamada "lenda negra" (VILARDAGA, 2010, p. 288).

No começo do século XVIII, ao soar dos primeiros conflitos entre colonos paulistas, descobridores das jazidas de ouro nas Minas Gerais, e aqueles que para ali afluíram em seguida, é reavivada a "lenda negra", como forma de diminuir os direitos originais de conquista. O estigma da insubordinação e barbárie faria as demandas dos homens de São Paulo menos dignas de consideração. No mesmo período, a capitania de São Paulo perde sucessivas extensões de terras, com a criação de novas divisões administrativas, ${ }^{12}$ e passa a ser subordinada à do Rio de Janeiro (1748-1765), sob a justificativa da necessidade de melhor proteção das áreas fronteiriças da colônia. É nesse contexto que Pedro Taques de Almeida Paes Leme redige seus textos genealógicos, primordialmente produzidos com fins à obtenção de privilégios e mercês para as principais famílias paulistas - dentre as quais figurava sua própria -, a partir de processos de nobilitação. ${ }^{13}$ Podemos dizer que Taques se apropriou

\footnotetext{
${ }^{11}$ Menção aos termos usados por Laura de Mello e Souza (2006) ao debater sobre as contradições entre imagens construídas sobre os paulistas ao longo do período colonial.

${ }^{12}$ Minas Gerais é feita capitania autônoma em 1720; os atuais estados do Rio Grande do Sul e Santa Catarina são destacados em 1738; Laguna em 1740; e os estados de Mato Grosso e Goiás logo depois, em 1748.

${ }^{13}$ Parte dos escritos foi perdida ao longo do tempo. Os títulos remanescentes estão disponíveis em formato transcrito e publicado, totalizando três volumes (LEME, 1980).
} 
da maneira como seus antecessores construíram suas demandas por recompensas, no passado não muito distante, ${ }^{14}$ alavancando-as à coletividade. ${ }^{15}$

Nos escritos genealógicos, destaca-se o uso do termo "paulista" não exatamente como toponímia, mas a partir de um conjunto bem definido e constante de predicados. Os homens assim denominados por Taques - a nomenclatura não é atribuída a nenhuma mulher - são aqueles que mais se enquadravam nas seguintes características: a ocupação de cargos de "governança da população", que configuravam posições de mando na vida política e participação em atividades militares; pedidos de mercês e privilégios, a partir de direitos presumidos, por conquista ou hereditariedade; atuação em guerras, independentemente de serem empreitadas oficiais; conquista de indígenas, com liberação de terras para ocupação e desenvolvimento de outras atividades; entradas para exploração de território ou "guerra aos gentios"; busca e "descobrimento" de minas de metais e pedras preciosas; disposição de cabedais próprios em empresas voltadas ao bem público, sendo prática destacada em referência à condição de "nobreza" e "vassalagem" (SANTOS, 2018, p. 141-150).

Taques retoma e consolida a relação entre os moradores de São Paulo e as conquistas empreendidas no território colonial, relacionando-as à ideia geral de subordinação à Coroa, que estaria implícita em suas ações. O autor ainda diferencia os "paulistas", mais associados às ações de defesa e descobrimento, dos "antigos paulistas", citados apenas coletivamente e em referência principalmente à captura de indígenas, construindo assim, a um só tempo, uma tradição de reverência ao soberano português - que justificaria os pedidos de nobilitação por hereditariedade - e um distanciamento das atividades mais violentas - adequado ao pretendido enobrecimento. Esse necessário afastamento faz-se presente também em relação aos grupos indígenas, que estavam imbricados nas famílias principais de São Paulo desde tempos remotos da colonização, em que eram comuns os matrimônios entre filhas de caciques e portugueses recém-chegados, tomando aquelas nomes lusófonos e assumindo esses o comando de grandes contingentes de nativos.

\footnotetext{
14 "Sagazes, [os sertanistas] haviam desenvolvido uma fórmula eficiente para o encaminhamento de suas pretensões, exagerando a relevância dos feitos e invocando, ao mesmo tempo, os sacrifícios e as tribulações sofridas para alcançá-los" (ROMEIRO, 2008, p. 242).

${ }^{15}$ Adriana Romeiro (2008, p. 257) afirma esse processo de coletivização das conquistas, ao remeter-se aos relatos produzidos sobre as descobertas auríferas, a fim de justificar o direito de conquista dos paulistas, na primeira metade do século XVIII: "Da dimensão individual, o feito dos descobrimentos assumiu uma dimensão coletiva, transformando-se na empresa heróica dos homens de São Paulo".
} 
À diferença de outros genealogistas e memorialistas, Taques confere pouco destaque às relações de parentesco entre adventícios e autóctones. As poucas menções a "mamelucos" ou "mamelucas" em seus escritos não se repetem entre os títulos, indicando assim serem secundárias em relação ao protagonismo dos "paulistas", cujas histórias de conquista repetem-se em diferentes pontos. O genealogista constrói ainda um panorama pouco harmônico entre "bastardos" - filhos de "paulistas" com mulheres indígenas - e legítimos - descendentes que se configuram como herdeiros nos textos e carregam os sobrenomes europeus de suas famílias. Mais do que isso, os matrimônios entre colonos e mulheres indígenas ganham destaque apenas quando datados das primeiras décadas de invasão portuguesa e, ainda assim, sem o uso de termos como "mameluco", "índio", "gentio" ou "cacique" - constantes em outras ocorrências -, atenuando as distinções entre os dois grupos e evitando enodoar as linhagens. Na retomada de autonomia da capitania de São Paulo, restaurada em 1765, a circulação dos textos de Taques entre as famílias da elite paulista coadunou-se com a reordenação da ocupação territorial em direção ao incremento da lavoura canavieira, seguindo os planos pombalinos instituídos desde a metrópole.

\section{4 - A historiografia de exaltação e sua difusão}

No início do século XIX, o café já teria se tornado mais atraente no mercado internacional do que a cana-de-açúcar, tendência que se confirmaria no decorrer do oitocentos. Com o reconhecimento do triunfo da dinâmica econômica cafeicultora na virada para o século XX, renova-se a historiografia paulística de exaltação, especialmente com a nomeação do engenheiro e historiador Affonso d'Escragnolle Taunay - já presente nos institutos históricos e geográficos nacional e paulista - como diretor do Museu Paulista, criado em 1894 (BREFE, 2011). A instituição, inicialmente de caráter naturalista, preparava-se para uma guinada calculada com a escolha do novo administrador. Nas palavras da historiadora Ana Claudia Fonseca Brefe,

Certamente, esta nomeação foi escrupulosamente calculada pelo governo do estado de São Paulo, dada a aproximação da comemoração do centenário da Independência brasileira, em 1922. A principal missão de Taunay ao assumir a direção do Museu era justamente preparar o Monumento do Ipiranga para o prestigioso aniversário, permitindo igualmente a São Paulo destacar-se no cenário nacional.

(...)

Entretanto, o gancho histórico escolhido por Taunay não é propriamente a proclamação da Independência, mas o advento deste evento em solo paulista e particularmente na colina 
do Ipiranga, lugar que ele e outros historiadores da mesma geração mostraram, através de seus estudos, ser reconhecido e importante desde o período colonial (BREFE, 2011, p. 143).

Esse destaque da proclamação da Independência e sua territorialização em solo paulista já figurava na própria estatística de Daniel Pedro Müller. No trecho citado, a autora assinala que Taunay teria deslocado o centro das comemorações, transferindo-o do lugar simbólico da "nação" para o lugar do espaço "paulista", tanto físico quanto imaginário. Em sua vasta obra escrita, o Ipiranga é revelado como parte do sistema de rotas e caminhos dos sertões, o que o vincula diretamente às movimentações bandeirantes, que por sua vez seriam responsáveis pelo alargamento das fronteiras e a conformação de limites, ainda no período colonial - praticamente idênticos aos da então nação brasileira que ora se celebrava.

Taunay compreendia claramente as funções e o potencial da iconografia e da museografia na construção de imagens históricas. Sob sua tutela, a dimensão imagético-pedagógica do Museu Paulista "foi concebida como uma representação visual do discurso historiográfico, uma espécie de 'manual tridimensional' da história brasileira de cunho paulista" (BREFE, 2011, p. 146). Pinturas e gravuras foram encomendadas; salas de exposição permanente foram montadas; e a decoração foi refeita, com destaque para o saguão principal, com esculturas e elementos representativos da grandeza, força e hegemonia do bandeirante no espaço e no tempo da história nacional. Esses recursos visuais tornaram-se componentes inalteráveis da edificação e, como pretendido, da historiografia brasileira.

Dessa maneira, a história nacional era superposta pela história dos paulistas - na figura da "raça de gigantes", assim nomeada pelo viajante Auguste Saint-Hilaire (1940 [1851], p. 32-33), no início do século XIX, e invocada nos escritos de Alfredo Ellis Jr. (1936, p. 177), publicados na primeira metade do século seguinte e pertencentes à linhagem historiográfica que argumentava em favor da superioridade biológica e política dos paulistas. ${ }^{16}$ Segundo esse autor, difusor prolixo da ideia de excepcionalidade, não apenas a conformação de isolamento combinado à mestiçagem teria resultado nessa peculiaridade, mas

\footnotetext{
${ }^{16}$ Segundo Katia Abud (1985), os trabalhos de Taunay, Ellis Jr. e do mencionado Alcântara Machado tomam os escritos de Pedro Taques e frei Gaspar como referências centrais, imputando a esses homens do século XVIII as origens da historiografia dos bandeirantes, apesar de que nenhum dos dois utiliza-se desse termo. É redundante, porém indispensável, afirmar que não coadunamos com a formulação desses historiadores, apreendendo os textos do setecentos principalmente a partir das definições que propõem.
} 
também o condicionamento imposto pelo regime de pequenas propriedades, que teria vigorado no planalto paulista durante o século XVII. Diz Ellis Jr.:

Pela publicação dos documentos dos Inventarios e Testamentos, bem como das Sesmarias, verifica-se que São Paulo no século XVII foi o centro de um enxame de fazendolas de pequena cultura e de pastoreio de diminutos rebanhos (ELLIS Jr., 1936, p. 250, grifos no original).

Além de "fazendolas", o autor usa ainda os termos "sitiecos", "reduzidíssima área" e "minúsculos estabelecimento rurais" até chegar à constatação de que "A divisão territorial seria pois baseada na pequena propriedade. Esse era o único regime permitido pelas circunstâncias que cercavam a colônia (...)" (ELLIS Jr., 1936, p. 251-253).

Tais considerações, reafirmadas nessas e n'outras páginas ao longo da obra, não são desinteressadas ou mero apontamento de revisão historiográfica em função das novas fontes. No capítulo anterior da mesma obra, "Psicologia do paulista", Ellis Jr. (1936) associa repetidamente as contingências econômicas dos primeiros tempos de colonização do planalto a um espírito de ordem prática que teria sido introjetado na estrutura psíquica dos bandeirantes e, assim, em seu modo de vida - algo próximo das noções de empreendedorismo transmitidas por viajantes que estiveram em São Paulo nas primeiras décadas do século XIX. Segundo Spix e Martius (1938, p. 205), estaria no encontro afortunado entre colonos e indígenas a origem do espírito empreendedor dos paulistas, sendo a sede da capitania palco do "mais livre desenvolvimento das condições civis". De modo geral, Rugendas (1949, p. 100) descreve a população como amante da liberdade e avessa às ordens da Coroa, nos primórdios da ocupação da capitania. Ele também observou o que denominou como ímpeto empreendedor dos paulistas, outrora vinculado aos combates militares e, naquele momento, no começo do oitocentos, dirigido ao cultivo da terra e à criação de animais.

Opondo-se à imagem dos paulistas como desafiadores insubordinados da Coroa, Ellis Jr. recorre a fontes oficiais recém-publicadas para construir uma narrativa em que o eventual excesso de ação particular era justificado pelo insulamento desse território. Em suas palavras, "Esse regime, pois, era de verdadeiro self government, saturado da democracia, na mais ampla acepção da palavra. Isso é o que ressalta clara e positivamente da leitura da documentação de publicação oficial" (ELLIS, Jr., 1936, p. 220).

Vale dizer que a ideia central contida nesses argumentos, da existência de um regime de pequenas propriedades e da preponderância de iniciativas individuais de caráter amplamente democráticas, bem como a escolha da expressão em inglês para defini-la, posicionam Ellis Jr. - mesmo que não 
declaradamente - na esteira dos trabalhos que referenciavam a Frontier Thesis, inaugurada por Frederick Jackson Turner (1994), em leitura proferida em 1893. A tese desse historiador justificava as características extraordinárias dos pioneiros estadunidenses - ou pioneers, no original - em função de suas práticas constantes na tomada de novas terras, percorrendo e povoando o território da costa leste à oeste. Em sua concepção, ele trata da fronteira como frontier e não border, ou seja, como espaço de expansão continuada - uma espécie de "sertão" - e não delimitação territorial - ou "confins".

Ressaltamos que, mesmo que a historiografia brasileira pouco tenha se distanciado da produção europeia, a experiência histórica e historiográfica proveniente dos Estados Unidos nos é relevante pela similaridade entre certas construções, tais como a ênfase nas empreitadas particulares e a utilização da natureza e do vasto território como imagens de unidade nacional. Não apenas a replicação ou o paralelismo entre historiografia brasileira e norte-americana foram registrados. Sérgio Buarque de Holanda foi igualmente conhecedor da Frontier Thesis e teve contato estreito com o espaço científico de produção histórica norte-americana. No entanto, manteve a formulação de que a expansão oeste encetada pelos paulistas não criou neles aspectos excepcionais, nem foi por isso motivada, sendo apenas manifestação dos intentos comuns aos colonos portugueses como um todo (HOLANDA, 2014). ${ }^{17}$

Podemos afirmar que a tese de Turner, em que pesem as muitas revisões e críticas elaboradas pela historiografia norte-americana, ${ }^{18}$ brasileira e brasi-

\footnotetext{
${ }^{17}$ Importante notar ainda a distinção entre os historiadores do século XIX e da primeira metade do século seguinte em relação às gerações que os sucederiam. Enquanto aqueles eram efetivamente parte das elites cujos interesses e representações são defendidos em suas narrativas historiográficas, o correr do século XX veria o surgimento e a ampliação de grupos destoantes desse contingente, ainda que não completamente autônomos em relação a ele. Tal alteração, articulada a novos debates teóricos no campo, no que se destacam a consolidação da Escola dos Annales e do desenvolvimento da micro-história italiana, trouxe mudanças significativas na produção acadêmica paulista, com a circunscrição de novos objetos de estudo, métodos e questões.

${ }^{18}$ As principais críticas acerca da tese de Turner podem ser assim elencadas: que apenas uma pequena porção da população esteve na situação da fronteira; que o foco nesse contexto tira atenção dos conflitos raciais e daqueles circunscritos ao espaço urbano; que veicularia preconceitos típicos do final do século XIX; além de questões acerca do formato de sua teoria, das metáforas usadas, do "evolucionismo" de seu pensamento, da imprecisão da delimitação da fronteira e do confronto de suas hipóteses com a contemporaneidade. Essa enumeração encontra-se na obra do professor de Estudos Americanos Alistair Hennessy (1978), que explora a ideia da fronteira em toda a América Latina, incluindo a experiência dos bandeirantes. Sua definição de "sertão", entretanto, refere-se mormente às regiões semiáridas. A discussão acerca dos limites da excepcionalidade das populações da fronteira, em moldes semelhantes ao
} 
lianista ${ }_{1}^{19}$ foi bem-sucedida no que diz respeito à criação de um imaginário nacional, de permanência ainda sensível em certas áreas e manifestações culturais e políticas estadunidenses - tal como a figura do bandeirante, no Brasil. Em ambos os mitos construídos, articulam-se as pessoas e os aspectos do território, bem como o próprio mover-se por ele, como elementos identitários, cuja síntese pode ser facilmente reproduzida. Recorre-se, portanto, ao espaço transformado pela ação humana - marcadamente contido na ideia de "marcha para o oeste" - como elemento unificador da nação, num processo que não possuía analogias no contexto europeu.

Diferentemente da ideia de uma marcha paulatina, contínua e constante em direção ao interior do continente, Sérgio Buarque de Holanda aponta que a ocupação dos confins coloniais teria sido realizada mais por movimento pendulares dos sertanistas, ${ }^{20}$ enquanto Dora Shellard Côrrea mobiliza a noção de "territórios étnicos"21 indígenas que passaram a fazer parte da própria maneira como os colonos de São Paulo deslocavam-se por e compreendiam os sertões. Assim, distante da experiência dos pioneers, os sertanistas - ou os bandeirantes - e seus grupos familiares, administrados e agregados deixaram poucos registros materiais perenes pelos territórios em que circulavam, empreendendo poucos esforços de fixação, do que resultou o padecimento frequente de vilas, povoações e estradas. No caso da capitania paulista, são ainda notáveis os malogrados esforços empreendidos pelo capitão-general

debate sobre a formação de um tipo-social ou uma espécie de raça nas terras de serra acima, pode ser também encontrada (ETULAIN, 1999).

${ }^{19}$ No contexto da historiografia brasileira e brasilianista, o tema da fronteira, a menção aos pioneiros e as comparações com os Estados Unidos foram frequentes desde o início do século $\mathrm{XX}$, tendo influências diretas nas obras dos intelectuais do período, incluindo Sérgio Buarque de Holanda, que frequentou o ambiente acadêmico estadunidense (WEGNER, 2000). Outra dimensão do debate encontra-se no campo do imaginário e das representações, relacionados à geografia, aos mitos e à expansão territorial (OLIVEIRA, 2000). Obras de meados do século XX, momento final de consolidação da ocupação do oeste paulista, com acentuada redução numérica dos indígenas e crescimento da industrialização na capital, também apontam para as comparações entre bandeirantes, fazendeiros e pioneiros, assinalando continuidades, rupturas e analogias (MOOG, 2000 [1955]; MONBEIG, 1998 [1952]).

${ }^{20}$ Trata-se de ideia de "equilíbrio vital", segundo a qual a ocupação territorial empreendida pelos colonos de São Paulo teria ocorrido por meio de movimentos de duração e intensidade variáveis (HOLANDA, 1966).

${ }^{21}$ Segundo Corrêa (2006), tanto os locais que continham as construções de moradias dos indígenas quanto as extensas matas em que realizavam atividades vitais - marcadamente, guerras, extrativismo, caça e comunicações - comporiam o território dominado ou utilizado pelos grupos nativos, não sendo adequada a oposição entre áreas ocupadas e desocupadas apenas a partir do critério de inexistência de grandes alterações humanas. 
D. Luís Antonio de Souza Botelho Mourão, $4^{\circ}$ morgado de Mateus, entre 1765 e 1775, na tentativa de consolidar a ocupação ao longo dos limites fronteiriços com a América espanhola (BELLOTTO, 2007).

De toda forma, as formulações embrenhadas na historiografia do mito fundante estadunidense foram inspiração certeira para a reconstrução da história paulista em fins do século XIX e começo do seguinte. Munida desse recontado imaginário, uma parcela das elites paulistas pôde criar bases sólidas e justificadas para a marcha que enfim realizaria - a ocupação do noroeste do estado paulista e a concomitante dizimação quase total dos grupos indígenas resistentes. A própria feitura do Mappa da Provincia foi indicativa da marcação do sertão como um projeto, como se nota no uso pioneiro de impressão por chapas de cobre, em substituição à manufatura, que respondia tanto à construção de uma representação racional quanto à possibilidade de usar as mesmas bases para futuramente preencher esses limites, à medida que os "sertões desconhecidos" ali marcados fossem efetivamente ocupados pelos planos de povoamento e agricultura. ${ }^{22}$ Nos quase cem anos decorridos entre a publicação do Mapa das Cortes e a dessa cartografia, constituiu-se uma transformação essencial da narrativa paulística, intrinsecamente atrelada a tais intentos, qual seja, o afastamento entre as elites de São Paulo e os grupos indígenas, além da reconfiguração da relação entre aquelas e o território, como se explicita na construção da ideia de "paulistas" empreendida por Pedro Taques. É notável que, a partir do princípio do século XX, a noção de "sertão" será identificada com as regiões mais áridas do nordeste, ficando associada às consequências devastadoras do clima seco e sendo geograficamente fixada. ${ }^{23}$

\footnotetext{
${ }^{22}$ Vê-se esse intento no ofício do então secretária da Assembleia Legislativa paulista, Joaquim Floriano de Toledo: "Preferem este expediente até por que havendo grandes espaços em claro no Mappa correspondentes aos lugares e sertoens desconhecidos, parece mais conveniente abrir-se a chapa de cobre por que a todo tempo se pode emendar os erros, ou fazer acrescentamentos a proporção das descobertas de explorações que se realizarem n'esses lugares" (Arquivo Público do Estado de São Paulo, Registro de Ofícios Diversos, ordem 874, caixa 79, pasta 2, documento 67 apud BEIER, 2015, p. 197, grifos nossos).

${ }^{23}$ Pode-se apreender a consolidação dessa noção de "sertão" nas obras de Josué de Castro (1965 [1946]), acerca da desnutrição e da fome no Brasil, e na literatura paradidática do início do século XX, escrita por Olavo Bilac e Manoel Bomfim (2000 [1910]). Em ambas, a cultura sertaneja e essa própria denominação são exclusivamente referentes ao interior do nordeste, especificamente às regiões de clima semiárido, com longos períodos de seca. A criação do "Polígono da Seca", demarcado em lei de 1936 e reforçado pela criação da Superintendência de Desenvolvimento do Nordeste (SUDENE) em 1959, contribuiu para enfatizar a associação entre as condições naturais e a definição de "sertão".
} 


\section{Figura 2}

\section{Mappa Chorographico da Provincia de São Paulo, 1841}

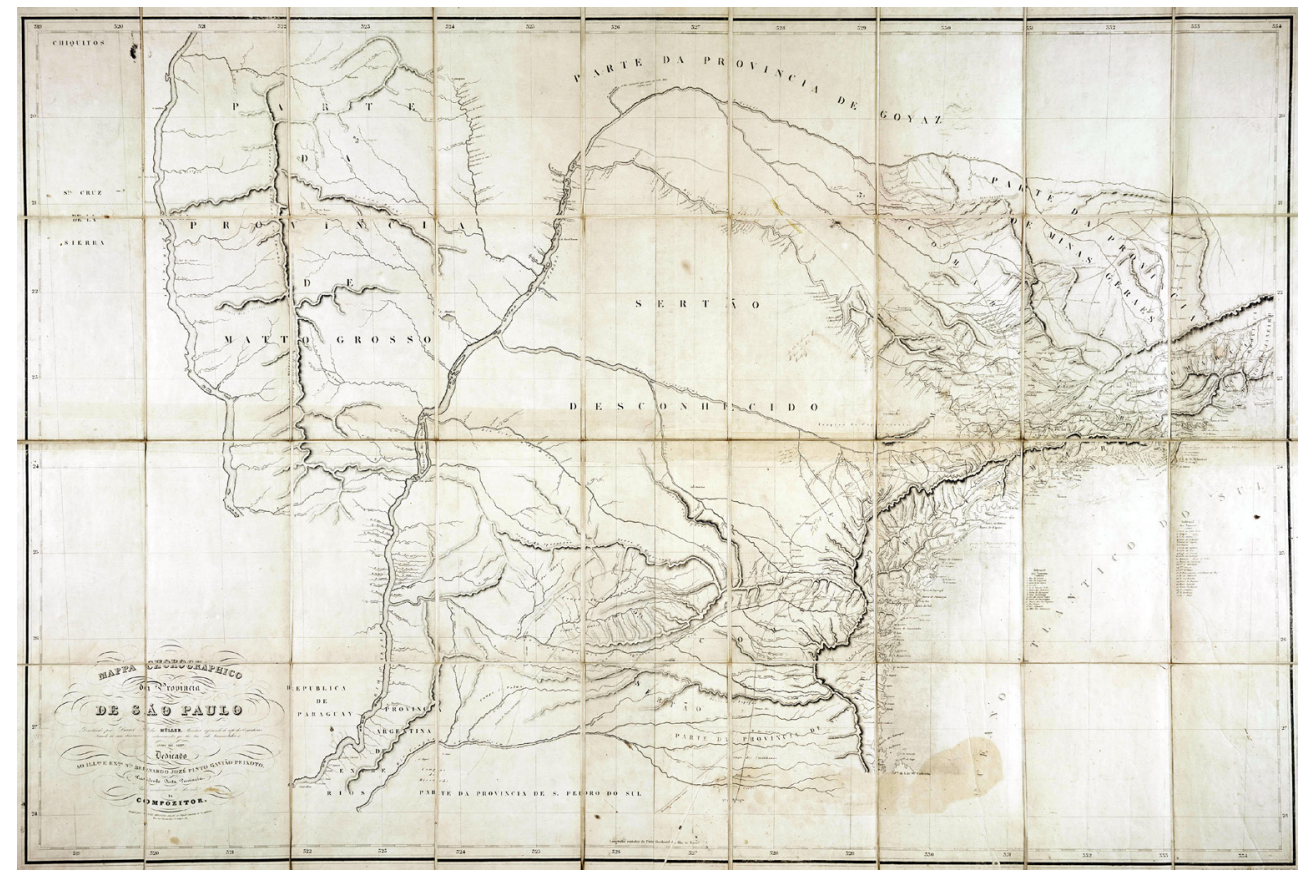

Fonte: Huntington Library, Rare Books Department, Maps. ${ }^{24}$

As áreas nomeadas por Daniel Pedro Müller como "sertão desconhecido" foram as últimas regiões a serem efetivamente apropriadas pelos fazendeiros paulistas no desenvolvimento da cafeicultura. Menos de um século depois da feitura do Mapa das Cortes, o argumentado domínio inquestionável dos sertanistas paulistas sobre os sertões meridionais - tese mobilizada pelos próprios e pela Coroa, ao sabor dos interesses, e articulada às imagens construídas sobre essa população - foi então apagado da representação oficial de seu território e substituído por uma sugestiva indagação, que conclamaria parte dos habitantes de São Paulo a uma nova conquista. Nas décadas seguintes, a categorização do oeste ainda vigoraria, com variações, tais como "terrenos despovoados" ou, já no período republicano, "terras pouco conhe-

\footnotetext{
${ }^{24}$ Dentre as cópias existentes do mapa, escolhemos a reprodução digitalizada da Huntington Library, pela melhor qualidade. No Brasil, há exemplares no acervo da Assembleia Legislativa de São Paulo e no Arquivo Público do Estado de São Paulo.
} 
cidas", ${ }^{25}$ mantendo a orientação geral de não reconhecimento da ocupação existente - composta por pequenos sitiantes e populações nativas e mestiças -, porém sem a menção ao termo e à imagem de "sertão".

O que foi subtraído do mapa provincial pode ser divisado nas pesquisas históricas, arqueológicas, etnológicas e etnográficas do século $\mathrm{XX}$, em diferentes discursos, quando parte dessa área estava em vias de ser tomada pela lavoura da rubiácea. No noroeste paulista, ainda nas primeiras décadas do dito século, predominavam grupos indígenas considerados pouco domesticáveis e agressivos, empecilhos ao desenvolvimento econômico, tal como descreve Egon Schaden, em artigo de 1954:

Ainda em princípios dêste século [XIX], grande parte do Estado figurava nos mapas como sertão desconhecido; era tôda a área ocidental, desde o baixo Tietê até às margens do Paranapanema, onde viviam as hordas setentrionais dos Kaingáng avêssas a qualquer aproximação com brancos em virtude de experiências negativas por que haviam passado no século anterior (SCHADEN, 1954, p. 6-9).

A situação dos Kaingang era especialmente sensível por estarem em área tão cobiçada pelos agentes do "progresso", ${ }^{26}$ atravancando a construção de ferrovias e a expansão das fazendas de café. Segundo Schaden, a centralidade do embate foi tamanha, que suas consequências tiveram repercussões para a totalidade dos indígenas no país, com o fortalecimento da iniciativa de criação do Serviço de Proteção aos Índios (SPI), que foi levada a cabo em 1910. Pouco tempo depois, seria "resolvida" a querela entre os paulistas e os nativos:

Aldeados daí a alguns anos em dois postos oficiais, na proximidade da vila de Braúna (Icatu e Vanuire), os Kaingáng deixaram de ser o 'terror da [Estrada de Ferro] Noroeste', como haviam sido alcunhados por quem lhes disputava o domínio das terras. Hoje não há quase matas em tôda aquela região; tudo está transformado em lavouras de café, de algodão, de mandioca, de milho. E os índios, reduzidos a menos de uma centena (...) (SCHADEN, 1954, p. 9).

O SPI, portanto, mostrou-se bem-sucedido na empreitada de "pacificação" dos indígenas, limitando-os a pequenos núcleos, reduzidos, pouco

\footnotetext{
${ }^{25}$ Essas nomenclaturas aparecem no Mappa da Provincia de São Paulo mandado organisar pela Sociedade Promotora de Imigração de S. Paulo e no Mappa do Estado de S. Paulo indicando a posição das Colonias existentes e em projecto, respectivamente publicados em 1886 e 1908.

${ }^{26}$ Note-se que desde o início do século XIX, o domínio ou "pacificação" dos Kaingang figurava no horizonte imediato dos principais da província, como se depreende pelas ações de aproximação empreendidas por João da Silva Machado, o barão de Antonina (WISSENBACH, 1995).
} 
expressivos e espoliados das matas que antes habitavam. É notável ainda um traço da cultura dos Kaingang mencionado pelo autor: "a ausência de rêde de dormir" (SCHADEN, 1954, p. 9), o que os afasta da cultura mameluca e, assim, das alianças construídas entre paulistas e indígenas - nomeadamente os Tupi -, que se traduziram na conquista mais rápida de certos territórios. Sobre o mesmo grupo, diz Hermann von Ihering, primeiro diretor do Museu Paulista, ainda um museu de história natural:

Os actuaes Índios do Estado de S. Paulo não representam um elemento de trabalho e de pro-
gresso. Como também nos outros Estados do Brazil, não se pode esperar trabalho sério
e continuado dos Índios civilizados e como os Caingangs selvagens são um impecilio para a
colonização das regiões do sertão que habitam, parece que não ha outro meio, de que se possa
lançar mão, senão o seu extermínio (IHERING, 1907, p. 215, grifos nossos).

Suas observações explicitam alguma continuidade em relação aos interesses postos desde fins do século XVIII, sob as ordens do futuro marquês de Pombal, também reverberada na aurora do oitocentos. Durante todo esse tempo - de 1765 ao começo do século XX -, a problemática dos grupos silvícolas permaneceu centrada nas intenções de desenvolvimento de um tipo de lavoura que requeria o trabalho regular e a liberação das terras. No momento em que escrevia Ihering, os resquícios da presença indígena estariam circunscritos às populações rurais, não tendo mais vínculos com as elites urbanas:

É interessante observar que na actual cultura da população rural podemos descobrir muitos vestígios da cultura indígena precedente. Os nomes d'um grande numero de localidades, montanhas, rios, etc., são derivados da linguagem tupi, e nas veias da maioria dos 'caboclos' ou 'caipiras' corre o sangue da raça de seus antecessores indios. (...)

A casa do 'caipira' não é, senão com pequenas modificações, a dos Guaranis. É interessante que assim muitos costumes prehistoricos se conservaram até os nossos dias e é provável que futuras investigações augmentem o numero destes achados, correspondentes a resíduos da edade de pedra (IHERING, 1907, p. 243-244).

Não é mais o sertanista, progenitor das famílias principais de São Paulo, cuja cultura embrenha-se no elemento indígena, e sim o "caipira" ou habitante das zonas agrícolas, pobre trabalhador rural. E as características que permaneceram no cotidiano dessas populações não remontariam ao período colonial - marcado pelo fulgor bandeirante -, pois seriam resquícios de um momento anterior, a chamada "pré-história americana". Efetiva-se, assim, por meio da cientifização dos indígenas - transfigurados em objetos 
de estudo e de questões sociais e econômicas, desde o século XIX,$-{ }^{27}$ um distanciamento que coloca essas populações em posição de subjugação.

O que procuro assinalar é que o espaço do "sertão desconhecido" da província paulista - em que floresceram inúmeras fazendas de café na segunda metade do século XIX e primeira do seguinte - era ocupado, quando se planejava a expansão agrícola, justamente pelo elemento do qual a antiga elite paulista buscava expressamente, há quase um século, afastar-se: o indígena. Esse alheamento, ainda que não se desse de forma definitiva no modo de vida, poderia assim o ser na esfera das representações - espaço em que se articulavam os paulistas, os demais habitantes, os indígenas, os planos administrativos e a própria produção de conhecimento de caráter histórico e identitário. Para tanto, era indispensável às elites paulistas desconstruir as narrativas que as associavam intrinsecamente aos sertões - como conjunto de pessoas e práticas -, circunscrevendo e delimitando esse espaço, diferenciando-se dele e finalmente, expulsando-o de seu território e, portanto, de sua imagem, ao mesmo tempo em que dele se apropriavam para seus interesses econômicos.

\section{5 - Os jornais estampam os novos domínios}

As famílias das elites de São Paulo, desde o século XVIII, empreenderam reflexões sobre si - como se vê pelos usos e apropriações das nomenclaturas de "sertanistas" e "paulistas", bem como da definição de uma maioria da população como "agricultores" -, reposicionando aquilo que foi sendo limado de seu território - o espaço do sertão -, em meio à elaboração de um imaginário de racionalização, elemento constitutivo dos processos de reordenamento do espaço e da população. Assim, chamo de "expulsão do sertão" precisamente a expulsão das relações entre os grupos principais da branquitude de São Paulo e os indígenas, ${ }^{28}$ a partir de uma articulação cons-

\footnotetext{
${ }^{27}$ Nos primeiros nove tomos da publicação do recém-criado Instituto Histórico e Geográfico Brasileiro, somam-se quase 30 textos sobre variados grupos indígenas. A transformação dos nativos em objetos de estudos históricos, antropológicos e sociais foi parte da crescente cientifização observada ao longo do oitocentos, bem como dos debates acerca da construção da identidade nacional e da integração dos grupos componentes da população do Império, em sua aurora (SANTOS, 2018, p. 232-234).

${ }^{28}$ Ainda que o presente artigo se concentre nas relações entre colonos de São Paulo e nativos, seria irresponsável ignorar o apagamento sofrido também pelas populações negras, especialmente presentes nas áreas urbanizadas da capitania e frequentemente aquilombadas nas imediações de vilas e da sede, não raro junto a indígenas (MOURA, 1959; MACHADO in PORTA, 2004).
} 
tante entre planos e construções materiais e imateriais. Essas duas dimensões apresentaram-se como colaborativas nesse arco de transformações e permanências, já que a presença historicizada - não folclorizada, circunscrita ao "caipira" ou como objeto antropológico - tornaria inevitável o reconhecimento da presença indígena na formação do território paulista e nacional e, portanto, da legitimidade de suas propriedades e de seus modos de vida. Convinha, então, encontrar ou criar outros lugares para os grupos nativos, tanto no passado quanto no presente - e ainda mais nas projeções futuras.

A efeméride dos 400 anos de fundação oficial da cidade de São Paulo, comemorada em 1954, permite investigar a permeabilidade da imprensa, do empresariado e do público leitor à construção do mito do bandeirante, bem como em que termos essa formulação estava colocada naquele momento, quando a própria elite paulista, ligada à cafeicultura e à industrialização, não pode mais ser considerada homogênea (LIMONGI, 2001, p. 138). Para Katia Abud,

\begin{abstract}
Os meios de comunicação passaram para o senso comum a imagem do Bandeirante: um homem destemido, de uma raça privilegiada, que levou o progresso e anexou ao Brasil, regiões muito distantes que hoje compõem o 'imenso' território nacional. Os meios de comunicação transmitiram (e continuam transmitindo) a imagem que os historiadores construíram, ao produzir o conhecimento histórico sobre as bandeiras. É verdade que há momentos em que a utilização dessa imagem se esvanece, e outros aos quais ela reaparece com muita força (ABUD, 1985, p. 182).
\end{abstract}

A autora refere-se especificamente ao período da chamada Revolução de 1932, entretanto tomo sua ressalva final no trecho transcrito para perscrutar as comemorações do IV Centenário, a partir de suas repercussões em alguns jornais paulistanos, ${ }^{29}$ especialmente no que tange à forma como são retratados os indígenas e a expansão territorial. Pode-se dizer que diversas empreitadas da elite paulista na primeira metade do século XX - culturais, intelectuais e políticas - fundamentaram-se, entre outros aspectos, em "concentrar seus esforços em atividades à altura dos seus antepassados" (LIMONGI, 2001, p. 146) e, por que não dizer, à sua imagem, algo especialmente notável e propício na mencionada efeméride. Destarte, nas primeiras duas

\footnotetext{
${ }^{29}$ A análise desses objetos ora proposta enfoca especificamente as representações das relações entre paulistas, indígenas e o território, sem abordar outros aspectos relevantes acerca de tais fontes, como as imagens e construções específicas dos anúncios dos jornais comemorativos (LOFEGO, 2006) e a criação de um imaginário de trabalho acerca da população e da cidade em meio à celebração (MOURA, 1994).
} 
páginas da edição comemorativa do Diario de S. Paulo, está estampado um poema de Guilherme de Almeida (1954, p. 1-2), intitulado "Acalanto de Bartira". O eu-lírico é a própria Bartira, cantando uma cantiga a seu filho, tido com o português João Ramalho, enquanto balançam na rede. No texto, a mãe, de origem indígena, filha do cacique Tibiriçá, representa a terra, tendo seu corpo mobilizado como parte da geografia da América portuguesa; enquanto o pai, português, simboliza o ímpeto da conquista. Do encontro desses dois elementos, surge uma "nova raça", sintetizada no filho, "feito de mar e feito de terra: / branco e moreno, de espuma e de chão, de alem e aquem-serra!". O movimento da rede é comparado às ondas do mar, esse trazendo Ramalho e aquele levando seus descendentes aos territórios desconhecidos.

Doravante, o autor constrói um percurso linear e cumulativo, entre vilas, paisagens, processos e acontecimentos, que podemos resumir no seguinte roteiro: Santo André; São Vicente; São Paulo; a mudança do núcleo para junto dos jesuítas; os ataques dos indígenas Tamoios; a exploração de ouro no Jaraguá; a coroação do filho, "neto de um rei da terra e filho de um deus do mar"; a ampliação da ocupação para além da Linha de Tordesilhas; a ação do bandeirante, "Dono das quatro direções / por onde fogem os sertões"; a descoberta aurífera nas Minas Gerais; o pagamento do Real Quinto, momento em que se sugere que os paulistas mandariam na Coroa portuguesa ("Por isso és capaz / de mandar, como mandas, / a um rei de outras bandas"); os conflitos com os emboabas; a "Solidão" após esses enfrentamentos, quando os paulistas empreenderam poucas atividades e os olhares do filho se voltam para outros horizontes; a cafeicultura; o "Rodeio"; e, finalmente, o epílogo, chamado "9 de Julho", em que o filho volta a ser "puro e central", nas lutas "Contra a desordem" (ALMEIDA, 1954, p. 1-2). Nessa linha, Almeida constrói um sentido para a miscigenação entre nativos e adventícios, circunscrita ao encontro inicial entre essas populações, ou seja, com o tom de "marco inaugural" ou "mito fundante". Há ilustrações, de autoria de Quirino da Silva, somente na primeira página, e todas referem-se ao imaginário indígena, de maneira similar aos desenhos de costumes e atividades dos grupos nativos encontrados nas bordas e nos vazios de mapas do Novo Mundo, desenhados desde as primeiras explorações marítimas originadas nos portos europeus em direção à América (ALEGRIA, 2007). 
As matérias dos periódicos são também referentes às comemorações, com destaque para os aspectos históricos ${ }^{30}$ e o desenvolvimento, supostamente ao longo de quatro séculos, da literatura, da imprensa, da indústria ${ }^{31}$ e de outros temas. ${ }^{32}$ Entre os artigos, são notáveis as referências aos primeiros homens da capitania, tal como na peça "Os trinta e dois companheiros de Martim Afonso e a cidade de São Paulo", em que Francisco de Assis Carvalho Franco (1954, p. 20-26) defende que a fundação de Piratininga - núcleo original de São Paulo - teria sido obra do donatário, ganhando direitos políticos anos depois, com a ereção de sua Câmara. A relevância do trabalho do povoador estaria, ainda, no grupo que teria trazido consigo, composto de membros de nobres famílias, cujos traços fidalgos seriam parte indissociável do âmago paulista - reverberando as construções nobiliárquicas de Pedro Taques. Conforme conclusão do autor, a nobreza desses homens seria o fundamento do sucesso posterior da cidade:

E ao terminar este nosso modesto ensaio, podemos tirar como conclusão que, desses trinta e dois fidalgos trazidos por Martim Afonso de Sousa e deixados como povoadores da capitania, a maioria deles dedicou dezenas de anos na defesa, na cristianização e na segurança do povoado humilimo de verdadeira taba indigena, que foi o inicio de São Paulo de Piratininga, entregando-o a seus posteros para que o preparassem para a visão clarividente do insigne colonizador que para ali os encaminhara, realizando enfim a missão grandiosa que lhe havia sido predestinada - de porta para a civilização de todo sul e sudoeste brasileiro, como de fato tem realizado e tem maravilhado a todos com seu extraordinario surto progressista que o transmudou numa das grandes capitais do mundo atual (FRANCO, 1954, p. 26).

\footnotetext{
${ }^{30}$ Os artigos publicados são de autoria de importantes pesquisadores e intelectuais do período e circunscrevem aspectos da formação da cidade, desde vila colonial (FERREIRA, 1954, p. 4; TAUNAY, 1954, p. 10-15; CORTESÃ̃, 1954, p. 16-18; VIOTTI, 1954, p. 8-9). Como observa Fernando Limongi (2001), o projeto cultural e político da elite paulista nas primeiras décadas do século XX tinha como um de seus horizontes a configuração de um sólido e direcionado ambiente universitário. Articulava-se a essa empreitada a atuação na formação de opinião, por meio dos textos veiculados em periódicos, destacadamente n'O Estado de S. Paulo, foco também da ação política de seus donos e mantenedores.

${ }^{31}$ Os textos sobre o desenvolvimento das artes, dos esportes e de outros aspectos buscam percorrer os quatro séculos da história paulistana, mesmo nos campos que podemos considerar inexistentes nos períodos mais remotos (ISGOROGOTA, 1954, p. 136, 140; KOPKE, 1954, p. 6; SILVEIRA, 1954, p. 8-9).

${ }^{32} \mathrm{O}$ próprio artigo de Egon Schaden, citado anteriormente, consta do exemplar comemorativo d'O Estado de S. Paulo (1954).
} 
A exaltação das qualidades dos colonizadores de São Paulo prossegue em texto de Almeida Magalhães, com menção ao espanto e aos previamente indicados termos usados por Saint-Hilaire, quando tratou da extensão territorial dos feitos desses homens:

Quando o fenomeno bandeirantista na sua formidavel atuação de duas longas centúrias - dentro das quis [sic] os paulistas, a principio os 'portuguezes de San Pablo', e mais tarde os mamelucos, vasculharam oito milhões e meio de quilometros quadrados, batendo o metal de lavagem, topando e descendo indios para o trabalho escravo, e, depois, deslumbrando o mundo, cuja facies iria transformar, com o grande ciclo do ouro e dos diamantes - fôr suficientemente conhecido, no Brasil e no estrangeiro, por sociologos, economistas e homens de pensamento, então, ninguem mais julgará exagerada a expressão Saint-Hilairiana, ante as façanhas de bandeirantes e monçoeiros: '... fica-se como estupefato e levado a crer que estes homens pertenciam a uma raça de gigantes' (MAGALHÃES, 1954, p. 123).

Em outro periódico, é reproduzido também um artigo especificamente sobre os bandeirantes, com alusão ao "valor indômito dos Paulistas", cujas ações são assim descritas:

Iam como um cataclismo desencadeado avassalando o continente com uma bravura e temeridade lendárias, levando tudo de vencida no arrôjo do tremendo arranco, aquêles nossos próceres - dignos troncos que robustecem a raça heróica dos Paulistas, que tão justamente se orgulham de ter por célular-mater os Bandeirantes! (NOBRE, 1954, p. 1).

Dessa maneira, os textos impressos nessas edições atualizam os valores celebrados por Taques - tais como a nobreza e a bravura -, inserindo-os na formação da cidade e em sua contemporaneidade. No entanto, é nas ilustrações e composições contidas nessas páginas, bem como nas homenagens feitas por empresas e associações, que encontramos a maior veiculação e reiteração de certas narrativas sobre o passado e seu legado. As associações entre os paulistas daquele momento e os de outrora são, por vezes, escancaradas, como consta na propaganda da Indústria de Pneumáticos Firestone, em que um enorme rosto de bandeirante repousa sobre o panorama da cidade, repleto de arranha-céus e fábricas, nos quais algumas mechas de sua barba se enroscam. O desenho é acompanhado de um texto, em que se lê a seguinte frase: "São, aproximadamente, 2.600.000 'Fernões Dias' - não só paulistas, mas de todos os Estados, de tôdas as raças - que vivem, incessantemente, procurando a 'esmeralda verde de um amanhã melhor...' (NOBRE, 1954, p. 7). 
As imagens de bandeirantes - nos moldes da iconografia encomendada por Affonso Taunay em sua gestão à frente do Museu Paulista, ${ }^{33}$ ou seja, ostentando trajes de couro, coletes, botas e chapéus, ${ }^{34}$ eretos e em postura de comando ${ }^{35}$ - proliferam entre os escritos, muitas vezes na posição de elo que une a vila colonial e seus aspectos naturais à metrópole de então e suas indústrias ou observando a cidade contemporânea, quase como se a supervisionassem ou apadrinhassem seu desenvolvimento.

A transformação da paisagem colonial em contemporânea é explicada, portanto, pela ação dos bandeirantes. Por sua vez, os indígenas, à exceção daqueles relacionados explicitamente com os primeiros colonizadores, são retratados coletivamente na posição de espectadores e contribuintes, tanto das empreitadas jesuíticas quanto das atividades dos colonos. Em um dos tributos comemorativos, da Empresa Brasileira de Relógios "Hora", vemos, ao fundo, a ilustração da primeira missa celebrada em Piratininga; em primeiro plano, um indígena observa a cena e, ao seu lado, constam os dizeres: "Olhemos o passado, aquela hora que assinalou a fundação de São Paulo, o instante maravilhoso em que bugres empenachados espiavam curiosos a celebração da primeira missa no Planalto" (Diario de S. Paulo, 1954, p. 14, grifos nossos). No anúncio da Estrada de Ferro Santos-Jundiaí, por cima do desenho da locomotiva nos trilhos figuram um bandeirante e um indígena, lado a lado, denotando a existência não apenas de contribuição, mas de harmonia entre ambos. ${ }^{36}$

33 Claudia Valladão de Mattos (1998/1999) dá-nos uma síntese das diretrizes e da evolução do programa de "decoração" encabeçado pelo historiador, para o qual foram realizadas encomendas a diversos pintores e escultores, cujas obras deram corpo e identidade aos agentes da história paulista e nacional. Os bandeirantes, grande destaque desse acervo, aparecem representados em poses heroicas, orientadas segundo uma tradição de pinturas de cunho histórico.

34 "As esculturas [encomendadas para o Museu Paulista] ressaltam a indumentária do bandeirante que ficou no imaginário popular - o chapéu com abas largas, botas de canos altos, bacamartes, polvarinho e facão. Duas esculturas apresentam o gibão de armas ou 'aramas de algodão', o 'esculpil dos hespanhóes', no dizer de Taunay" (MAKINO, 2002/2003, p. 174).

${ }^{35}$ Nesses desenhos, sua altivez é associada diretamente à consagração de uma ética de trabalho incansável, com adjetivações escritas como "nobre e laborioso povo paulistano" e "operosa gente bandeirante", além de descrições, tais como "Aos pioneiros, que já quatro séculos deram início a êste milagre continuado de trabalho, de progresso, de lutas e de glórias que têm sido a vida de São Paulo [...]". Com essa caracterização, o mito do bandeirante podia servir agora aos interesses de continuado florescimento da indústria, em consonância com a dinâmica da nova metrópole (Diario de S. Paulo, 1954, caderno 1, p. 16; caderno 2, p. 11; caderno 2, p. 6).

${ }^{36}$ É indispensável fazermos menção aos esforços recentes empreendidos por pesquisadores e pesquisadoras do Museu Paulista (MP) - antigo Museu do Ipiranga -, agora vinculado à Universidade de São Paulo, no sentido de problematizar a produção e o uso do imaginário acerca dos bandeirantes, veiculado nos quadros, gravuras e esculturas encomendados por 
As imagens de nativos e colonizadores, leigos ou religiosos, em completo acordo contrastam não só com o período colonial, mas com a batalha então em curso no ainda "sertão desconhecido", onde ferrovias e grandes lavouras arrasavam os territórios indígenas, constituindo "novas bandeiras" ${ }^{37}$ Nas representações vigentes em meados do século XX, formuladas a partir do trabalho de alguns historiadores e propagadas nos periódicos mencionados e em outros meios, os autóctones haviam cumprido suas atribuições, quais fossem, de concorrer para a formação da vila e depois cidade de São Paulo. Sua presença tributária deveria restringir-se a esse passado remoto, e não havia espaço - material e imaterial - para sua existência no presente. Pode-se dizer que a dissociação derradeira entre os paulistas e os indígenas, expressa sem conflito ou questionamento nessas imagens do bandeirantismo, decorreu de um longo processo de acúmulos, sobreposições, criações e apropriações, no qual figuram as representações de "sertanistas", "paulistas" e "agricultores" - construídas e difundidas com fins específicos, mas mantidas no imaginário sobre São Paulo mesmo após o esfacelamento de seus contextos imediatos de origem.

Entre meados do século XVIII e as primeiras décadas do oitocentos, os moradores principais de São Paulo deixaram de ser reconhecidamente homens dos sertões e transfiguraram-se nas elites que encampavam a apropriação do território paulista por meio de um instrumental de racionalização e mediação, no qual estatísticas e mapas criavam direcionamentos explícitos para seus empreendimentos econômicos, políticos e sociais, nomeadamente a agricultura exportadora. Nesse tempo, entre permanências e transformações, as sucessivas elites paulistas expulsaram o sertão de sua representação coletiva, retomando essa categoria territorial apenas como estímulo para as novas empreitadas, nas quais não havia mais possibilidades de quaisquer relações com os indígenas que não fossem o confronto e a obliteração. Dentro desse panorama, historiografia, imprensa, política e intelectualidade acadêmica foram campos em disputa, em meio à diversificação da elite eco-

\footnotetext{
Taunay, expostos até hoje na instituição e reproduzidos em livros didáticos e outros materiais, muitas vezes como exemplares "genuínos" do período que retratam, apesar de terem sido feitos já no século XX. A título de exemplo, citamos as exposições "Imagens Recriam a História" e "Bandeirante: um personagem em debate", inauguradas respectivamente em 2007 e 2017, cujos conteúdos explicitavam os processos de encomenda e divulgação das obras que compõem a decoração do MP, bem como as contradições entre os agentes históricos nelas reproduzidos.

${ }^{37}$ A expressão, reproduzida por Katia Abud (1985, p. 199), é originária da obra de Cassiano Ricardo (1940).
} 
nômica e cultural sediada em São Paulo (não necessariamente paulista). Enquanto sua parcela mais tradicional havia se pronunciado em seus jornais, ainda na República Velha, contra o cálculo de que seu voto valesse o mesmo que de um empregado seu (LIMONGI, 2001), a Universidade de São Paulo, encampada originalmente por esses mesmos grupos e famílias, tornava-se paulatinamente lugar possível para indivíduos mais próximos dos empregados do que de seus patrões, ou ao menos situados entre esses dois universos.

A maior amplitude da academia não era, decerto, projeto declarado das elites tradicionais, senão a conjugação dos esforços de agentes externos a ela e de outras circunstâncias, tais como o desinteresse dos primeiros ingressantes, oriundos dos altos círculos culturais e econômicos paulistas, na completude dos cursos e a necessidade de formação de quadros docentes para o encaminhamento da reforma pretendida no ensino secundário (LIMONGI, 2001). Nessas fendas, a oportunidade de obter um diploma de ensino superior era significante da possibilidade de ascensão social para famílias remediadas e imigrantes. Na mesma década de 1950 - em que as celebrações "quatrocentonas" buscaram, como visto, consolidar um conjunto de representações palatável e evolutivo sobre a sociedade e o território de São Paulo -, o meio acadêmico paulista começa a ser atravessado por experiências e vozes dissonantes. Em 1951, Florestan Fernandes - filho de empregada doméstica e neto de trabalhador rural - doutora-se na Faculdade de Filosofia, Letras e Ciências Humanas da USP, com a tese A função social da guerra na sociedade tupinambá, ingressando posteriormente em seu corpo docente; no final do mesmo decênio, Clóvis Moura - piauiense estabelecido em São Paulo há poucos anos - publica a obra Rebeliões da senzala, em que aponta para a constância e impetuosidade da resistência negra à escravidão na América portuguesa, bem como as repetidas alianças entre escravizados e indígenas nessas ações. Em 1982, Moura receberia o título de especialista por notório saber na própria FFLCH-USP, como requisito para compor a banca de mestrado de Miriam Ferrara, cuja dissertação intitulava-se A imprensa negra paulista (19151963): estudo monográfico (VIEIRA, 2019).

É notável que Fernandes e Moura - para mencionar apenas dois exemplos - sejam não apenas de origens consideravelmente distantes das elites culturais e econômicas tradicionais de São Paulo, mas também tenham tido trajetórias em que se entrelaçavam a abordagem sistemática de temas de pesquisa inexistentes nesses círculos - marcadamente voltando seus olhares para as populações negras e ameríndias e contrapondo-se a algumas análises clássicas do pensamento brasileiro sobre elas - e a atuação política, tanto de maneira partidária como ativista. A pesquisa de Clóvis Moura sobre a 
imprensa negra é sugestão de continuidade e aprofundamento para o próprio artigo que ora se encerra. Às vésperas do bicentenário da Independência, comemoração para a qual novamente os grupos intelectuais paulistas concorrem com afinco, o panorama explorado nesse texto convoca-nos a atentar para a racialização, a obliteração e a folclorização na construção do imaginário sobre a terra e os grupos populacionais que a disputam.

\section{Referências Bibliográficas}

ABUD, Katia Maria. O sangue intimorato e as nobilíssimas tradições: a construção de um símbolo paulista: o bandeirante. 1985. Tese (Doutorado) - Faculdade de Filosofia, Letras e Ciências Humanas, Universidade de São Paulo, São Paulo, 1985.

ALEGRIA, Maria Fernanda et al. Portuguese Cartography in the Renaissance. In: WOODWARD (ed.), The History of Cartography, v. 3: Cartography in the European Renaissance. Chicago; London: The University of Chicago Press, 2007, p. 977-1059.

BEIER, José Rogério. Artefatos de poder: Daniel Pedro Müller, a Assembleia Legislativa e a construção territorial da província de São Paulo (1835-1849). 2015. Dissertação (Mestrado) - Faculdade de Filosofia, Letras e Ciências Humanas, Universidade de São Paulo, São Paulo, 2015.

BELLOTTO, Heloísa Liberalli. Autoridade e conto no Brasil colonial: o governo do Morgado de Mateus em São Paulo (1765-1775). São Paulo: Alameda, 2007.

BILAC, Olavo; BOMFIM, Manoel. Através do Brasil: prática de língua portuguesa. São Paulo: Companhia das Letras, 2000 [1910].

BLAJ, Ilana. A trama das tensões: o processo de mercantilização de São Paulo colonial (1681-1721). São Paulo: Humanitas; Fapesp, 2002.

BREFE, Ana Claudia Fonseca. Paradigma da história nacional? O Museu Paulista ao longo do século XX. In: SEMINÁRIO INTERNACIONAL MUSEUS NACIONAIS E OS DESAFIOS CONTEMPORÂNEOS, 2010, Rio de Janeiro. Museus nacionais e os desafios do contemporâneo. Rio de Janeiro: Museu Histórico Nacional, 2011, p. 136-154.

BRUNO, Ernani Silva. História e tradições da cidade de São Paulo: Volume I - Arraial de Sertanistas (1554-1828). São Paulo: Editora Hucitec, 1991.

CANDIDO, Antonio. Os parceiros do Rio Bonito: estudo sobre o caipira paulista e a transformação dos seus meios de vida. São Paulo: Duas Cidades; Ed. 34, 2001.

CASTRO, Josué. Geografia da fome (o dilema brasileiro: pão ou aço). São Paulo: Brasiliense, 1965 [1946].

CINTRA, Jorge Pimentel. O Mapa das Cortes: perspectivas cartográficas. Anais do Museu Paulista, São Paulo, nova série, v. 17, n. 2, p. 63-77, jul./dez., 2009. Disponível em: https://www.scielo.br/pdf/anaismp/v17n2/05.pdf. Acesso em: 23 abr. 2021. Doi: https://doi.org/10.1590/S0101-47142009000200005.

COMISSÃO DO IV CENTENÁRIO DA FUNDAÇÃO DA CIDADE DE SÃO PAULO. São Paulo em Quatro Séculos. São Paulo: Comissão do IV Centenário da Fundação da Cidade de São Paulo; Instituto Histórico e Geográfico de São Paulo, 1953. 
CORRÊA, Dora Shellard. Historiadores e cronistas e a paisagem da colônia Brasil. Revista Brasileira de História, São Paulo, v. 26, n. 51, p. 63-87, 2006. Disponível em: https://www.scielo.br/pdf/rbh/v26n51/05.pdf. Acesso em: 23 abr. 2021. Doi: https://doi.org/10.1590/S0102-01882006000100005.

CORTESÃO, Jaime Zuzarte. Alexandre de Gusmão E o Tratado de Madrid, t. 2. São Paulo: Imprensa Oficial; Fundação Alexandre de Gusmão, 2006.

ELLIS Jr., Alfredo. Os primeiros troncos paulistas e o cruzamento euro-americano. São Paulo: Ed. Nacional, 1936.

ETULAIN, Richard. (org.). Does the Frontier Experience Make America Exceptional?. Boston; Nova Iorque: Bedford; St. Martin's, 1999.

HENNESSY, Alistair. The Frontier in Latin American History. Albuquerque: University of New Mexico Press, 1978.

HOLANDA, Sérgio Buarque de. Movimentos da população em São Paulo no século XVIII. Revista do Instituto de Estudos Brasileiros, São Paulo, n. 1, p. 55-111, 1966. Disponível em: https://www.revistas.usp.br/rieb/article/view/45622/49221. Acesso em: 23 abr. 2021. Doi: https://doi.org/10.11606/issn.2316-901X.v0i1p55-111.

HOLANDA, Sérgio Buarque de. Monções. São Paulo: Companhia das Letras, 2014.

IHERING, Hermann von. A anthropologia do estado de São Paulo. Revista do Museu Paulista, São Paulo, v. VII, p. 202-257, 1907.

KOK, Glória. O sertão itinerante: expedições da capitania de São Paulo no século XVIII. São Paulo: Editora Hucitec; Fapesp, 2004.

LEME, Pedro Taques de Almeida Paes. Nobiliarquia Paulistana Histórica e Genealógica, t. I-III. 5 ed. Belo Horizonte; São Paulo: Ed. Itatiaia; Ed. da Universidade de São Paulo, 1980.

LIMONGI, Fernando. Mentores e clientelas da Universidade de São Paulo. In: MICELI, Sergio (org.). História das ciências sociais no Brasil, v. 1. São Paulo: Editora Sumaré, 2001, p. 135-221.

LOFEGO, Silvio Luiz. A construção da memória na publicidade do IV Centenário da cidade de São Paulo. Patrimônio e Memória, Assis, v. 2, n. 2, p. 25-44, 2006.

MACHADO, José de Alcântara. Vida e morte do bandeirante. Belo Horizonte; São Paulo: Ed. Itatiaia; Ed. da Universidade de São Paulo, 1980 [1929].

MACHADO, Maria Helena. Sendo cativo nas ruas: a escravidão urbana na cidade de São Paulo. In: PORTA, Paula (org.). História da Cidade de São Paulo. São Paulo: Paz e Terra, 2004, p. 59-99.

MAKINO, Miyoko. Ornamentação do Museu Paulista para o Primeiro Centenário: construção de identidade nacional na década de 1920. Anais do Museu Paulista, São Paulo, nova série, v. 10/11, p. 167-195, 2002/2003. Disponível em: https:// www.scielo.br/pdf/anaismp/v10-11n1/10.pdf. Acesso em: 23 abr. 2021. Doi: https://doi.org/10.1590/S0101-47142003000100010.

MARCÍLIO, Maria Luiza. Crescimento demográfico e evolução agrária paulista: 1700-1836. São Paulo: Hucitec; Edusp, 2000. 
MATTOS, Claudia Valladão de. Da Palavra à Imagem: sobre o programa decorativo de Affonso Taunay para o Museu Paulista. Anais do Museu Paulista, São Paulo, nova série, v. 6/7, p. 123-145, 1998/1999. Disponível em: https://www.revistas. usp.br/anaismp/article/view/5363/6893. Acesso em: 23 abr. 2021. Doi: https:// doi.org/10.1590/S0101-47141999000100006.

MONBEIG, Pierre. Pioneiros e fazendeiros de São Paulo. 2 ed. São Paulo: Hucitec; Polis, 1998 [1952].

MOOG, Clodomiro Vianna. Bandeirantes e Pioneiros: Paralelo entre duas culturas. 19 ed. Rio de Janeiro: Graphia, 2000 [1955].

MOURA, Clóvis. Rebeliões da senzala: quilombos, insurreições, guerrilhas. São Paulo: Edições Zumbi, 1959.

MOURA, Esmeralda Blanco Bolsonaro de. Bandeirantes do progresso: imagens do trabalho e do trabalhador na cidade em festa. São Paulo, 25 de janeiro de 1954. Revista Brasileira de História, São Paulo, v. 14, n. 28, p. 231-246, 1994.

MÜLLER, Daniel Pedro. Ensaio d'um quadro estatístico da província de São Paulo. 3 ed. São Paulo: Governo do Estado, 1978 [1838].

NOVAIS, Fernando. O reformismo ilustrado luso-brasileiro: alguns aspectos. Revista Brasileira de História, São Paulo, n. 7, p. 105-118, 1984.

ODALIA, Nilo (org.); CALDEIRA, João Ricardo de Castro (org.). História do Estado de São Paulo: a formação da unidade paulista. República, v. 2. São Paulo: Editora UNESP; Imprensa Oficial; Arquivo Público do Estado, 2010.

OLIVEIRA, Lúcia Lippi. Americanos: Representações e identidade nacional no Brasil e nos EUA. Belo Horizonte: Editora UFMG, 2000.

RENDON, José Arouche de Toledo. Obras. São Paulo: Governo do Estado de São Paulo, 1978.

ROMEIRO, Adriana. Paulistas e emboabas no coração das Minas: Idéias, práticas e imaginário político no século XVIII. Belo Horizonte: Editora UFMG, 2008.

RUGENDAS, Johann Moritz. Viagem pitoresca através do Brasil. São Paulo: Livraria Martins Editora, 1949.

SAINT-HILAIRE, Auguste. Viagem à Província de São Paulo. São Paulo: Martins, 1940 [1851].

SANTOS, Amália Cristovão dos. A expulsão do sertão: elites paulistas, entre o imaginário e o território (1749-1841). 2018. Tese (Doutorado) - Faculdade de Arquitetura e Urbanismo, Universidade de São Paulo, São Paulo, 2018.

SOUZA, Laura de Mello e. O sol e a sombra: Política e administração na América portuguesa do século XVIII. São Paulo: Companhia das Letras, 2006.

SPIX, Johann Baptist von; MARTIUS, Carl Friedrich Phillipp von. Viagem pelo Brasil. Rio de Janeiro: Imprensa Nacional, 1938.

TURNER, Frederick Jackson. Rereading Frederick Jackson Turner: "The Significance of the Frontier in American History" and Other Essays. Nova Iorque: Henry Holt and Company, 1994.

VIEIRA, Cleber Santos. Prefácio: um rosário de lutas. In: MOURA, Clóvis. Sociologia do negro brasileiro. 2 ed. São Paulo: Perspectiva, 2019, p. 15-28. 
VILARDAGA, José Carlos. São Paulo na órbita do Império dos Felipes: conexões castelhanas de uma vila da América portuguesa durante a União Ibérica (1580-1640). 2010. Tese (Doutorado) - Faculdade de Filosofia, Letras e Ciências Humanas, Universidade de São Paulo, São Paulo, 2010.

WEGNER, Robert. A conquista do oeste: A fronteira na obra de Sérgio Buarque de Holanda. Belo Horizonte: Editora UFMG, 2000.

WISSENBACH, Maria Cristina Cortez. Desbravamento e catequese na constituição da nacionalidade brasileira: as expedições do Barão de Antonina no Brasil meridional. Revista Brasileira de História, São Paulo, v. 15, n. 30, p. 137-155, 1995.

\section{Periódicos}

A Gazeta. São Paulo, ano XLVIII, n. 14.590, 25 jan. 1954.

Diario de S. Paulo. São Paulo, ano XXVI, n. 7.647, 25 jan. 1954.

O Estado de S. Paulo. São Paulo, ano LXXV, n. 24.145, 25 jan. 1954.

\section{Artigos de Jornais}

ALMEIDA, Guilherme. Acalanto de Bartira. Diario de S. Paulo, São Paulo, ano XXVI, n. 7.647, 25 jan. 1954, caderno 1, p. 1-2.

CORTESÃO, Jaime Zuzarte. Martim Afonso de Sousa e a fundação de São Paulo. O Estado de S. Paulo, São Paulo, ano LXXV, n. 24.145, 25 jan. 1954, p. 16-18.

FERREIRA, Otavio. Os vários tipos de navios da época dos descobrimentos. $O$ Estado de S. Paulo, São Paulo, ano LXXV, n. 24.145, 25 jan. 1954, p. 4.

FRANCO, Francisco de Assis Carvalho. Os trinta e dois companheiros de Martim Afonso e a cidade de São Paulo. O Estado de S. Paulo, São Paulo, ano LXXV, n. 24.145, 25 jan. 1954, p. 20-26.

ISGOROGOTA, Judas. História das Artes Plásticas em São Paulo. A Gazeta, São Paulo, ano XLVIII, n. 14.590, 25 jan. 1954, p. 136, 140.

KOPKE, Carlos Burlamaqui. Quatro séculos de literatura. Diario de S. Paulo, São Paulo, ano XXVI, n. 7.647, 25 jan. 1954, caderno 1, p. 6.

MAGALHÃES, Almeida. Bandeirantes: "Estes homens pertenciam a uma raça de gigantes". A Gazeta, São Paulo, ano XLVIII, n. 14.590, 25 jan. 1954, p. 123.

NOBRE, Fernando. Os bandeirantes. Diario de S. Paulo, São Paulo, ano XXVI, n. 7.647, 25 jan. 1954, caderno 7, p. 1.

SCHADEN, Egon. Os primitivos habitantes do território paulista. O Estado de S. Paulo, São Paulo, ano LXXV, n. 24.145, 25 jan. 1954, p. 6-9.

SILVEIRA, Luiz. A imprensa paulista. Diario de S. Paulo, São Paulo, ano XXVI, n. 7.647, 25 jan. 1954, caderno 2, p. 8-9.

TAUNAY, Affonso d'Escragnolle. João Ramalho e São Paulo. O Estado de S. Paulo, São Paulo, ano LXXV, n. 24.145, 25 jan. 1954, p. 10-15. 
VIOTTI, Helio Abranches. A fundação de São Paulo pelos jesuítas. Diario de S. Paulo, São Paulo, ano XXVI, n. 7.647, 25 jan. 1954, caderno 1, p. 8-9.

\section{Cartografias}

Mapa dos confins do Brazil com as terras da Coroa da Espanha na América Meridional. [S.l.: s.n.], 1749. 1 mapa ms.: col.; 60 x 54cm. em f. 70 x 64. Biblioteca Nacional do Rio de Janeiro.

Mappa Chorographico da Provincia de São Paulo. Paris: Alexis Orgiazzi, [1841]. 1 mapa, impr: 100 x $72 \mathrm{~cm}$. Arquivo Público do Estado de São Paulo.

Mappa da Provincia de São Paulo mandado organisar pela Sociedade Promotora de Imigração de S. Paulo. Rio de Janeiro: Lith. Paulo Robin $\mathcal{E}$ Cia, 1886. 1 mapa color; 38 x 58 cm. Arquivo Público do Estado de São Paulo.

Mappa do Estado de S. Paulo indicando a posição das Colonias existentes e em projecto [1908]. O Immigrante, São Paulo, ano 1, n. 1, jan., 1908. Arquivo Público do Estado de São Paulo.

Recebido: 03/07/2020 - Aprovado: 15/03/2021

Editores Responsáveis

Júlio Pimentel Pinto e Flavio de Campos 